\title{
Errata
}

ISSN 1678-3921

Journal homepage: www.embrapa.br/pab

ERRATA: Liming, fertilization,

For manuscript submission and journal contents, access: www.scielo.br/pab

\section{and rhizobia inoculation on cowpea yield in a Brazilian Amazon upland forest environment}

In the paper "Liming, fertilization, and rhizobia inoculation on cowpea yield in a Brazilian Amazon upland forest environment", DOI: 10.1590/ S1678-3921.pab2021.v56.02191, published in Pesquisa Agropecuária Brasileira, v.56, e02191, 2021, on page 1, left column, line 1, in the address note of Wardsson Lustrino Borges, where it reads:

"(1凶),

it should read:

“(1,2凶)". 